\title{
Effects of Salicylic Acid on Gaba Metabolism in Pepper Plants under Stress Conditions
}

\author{
Salisilik Asitin Stres Koşulları Altında Biber Bitkisinde Gaba \\ Metabolizması Üzerine Etkisi
}

\author{
Research Article \\ Fazilet Özlem Çekiç \\ Biology Department, Faculty of Science and Letters, Aksaray University, Aksaray, Turkey.
}

\section{A B STRACT}

\begin{abstract}
alicylic acid (SA) is a potential plant hormone that enhances the capacity of plants to cope with various stress $\checkmark$ factors. Gamma-aminobutyric acid (GABA) is an important non-protein amino acid, which is increased by stress conditions. However, the interaction between SA and GABA is not well known. In this response the aim of this study was to evaluate the effects of SA on GABA metabolism in pepper plants (Capsicum annuum L.) under individual and combined salt $(\mathrm{NaCl})$ and polyethylene glycol $(\mathrm{PEG})$ induced osmotic stresses. Total chlorophyll content, the activities of glutamate dehydrogenase (GDH, EC 1.4.1.4) and glutamate decarboxylase (GAD, EC 4.1.1.15), GABA content were analyzed in the leaves of pepper plants. Total chlorophyll content was decreased by combined salt and PEGinduced osmotic stresses. Individual SA, NaCl and PEG applications increased GDH activity. Under stress conditions, SA did not enhance GDH activity; however, GAD activity was increased within these conditions. Our results showed that salicylic acid application did not enhance GABA accumulation during individual and combined stress conditions. The dose and application process of SA could lead to this result. However further studies should be done to identify the interaction between SA and GABA under various stress conditions.
\end{abstract}

\section{Key Words}

Capsicum annuum L., GABA, salt stress, osmotic stress, SA.

\section{öz}

\begin{abstract}
Calisilik asit (SA), bitkilerin çeşitli stres faktörlerine karşı korunma kapasitelerini artıran potansiyel bir bitki hormonudur. Gama-aminobütirik asit (GABA) stres koşullarında artan protein yapısında olmayan önemli bir amino asittir. Bununla birlikte, SA ve GABA arasındaki ilişki tam olarak bilinmemektedir. Bu çalışmanın amacı, tek ve birlikte uygulanan tuz $(\mathrm{NaCl})$ ve polietilen glikol (PEG) ile indüklenen ozmotik stres koşullarında biber bitkisinde (Capsicum annuum L.) SA'nın GABA metabolizması üzerine etkilerinin incelenmesidir. Biber bitkisinin yapraklarında toplam klorofil miktarı, glutamat dehidrogenaz (GDH, EC 1.4.1.4) ve glutamat dekarboksilaz (GAD, EC 4.1.1.15) aktiviteleri ile GABA miktarı analiz edilmiştir. Toplam klorofil miktarı birlikte uygulanan tuz ve PEG'in indüklediği ozmotik stres koşullarında azalmıştır. SA, NaCl ve PEG'in tekli uygulamaları GDH aktivitelerini artırmıştır. Stres koşulları altında SA, GDH aktivitesini artırmamıştır; bununla birlikte GAD aktivitesi bu koşullar altında artmıştır. Sonuçlara göre, salisilik asit uygulaması tekli ve kombine stres koşullarında GABA birikimi artırmamıştır. SA'nın doz ve uygulama süreci bu sonuca neden olabilir. Bununla birlikte SA ve GABA arasındaki ilişkiyi belirlemek için farklı stres koşullarında çeşitli çalışmalar yapılmalıdır.
\end{abstract}

\section{Anahtar Kelimeler}

Capsicum annuum L., GABA, tuz stresi, ozmotik stres, SA.

Article History: Received: Apr 15, 2017; Revised: Jun 25, 2017; Accepted: Oct 10, 2017; Available Online: Dec 25, 2017. DOI: $10.15671 /$ HJBC.2017.167

Correspondence to: F.Ö. Çekiç Biology Department, Faculty of Science and Letters, Aksaray University, Aksaray, Turkey. 


\section{INTRODUCTION}

3 lants have to cope with various abiotic stresses such as drought and salinity that cause a decrease in plant productivity. However under these conditions, the accumulation of stress-related hormones such as salicylic acid (SA) could be changed rapidly [1]. In plants, SA could be identified as an effective therapeutic agent that regulates various physiological and biochemical processes during their life cycle $[2,3]$.

The role of SA in response to pathogens has been intensively focused. SA plays also an important role in response to various environmental stresses such as salinity, chilling, heat, heavy metal and osmotic stresses $[2,4]$. In recent years, SA is suggested to be a promising compound within its effect on eliminating the deleterious effects of stress factors, and it is suggested to be a complex signal transduction network. However, the impact of SA could be changed according to the application and the plant species [5].

GABA is a four carbon non protein amino acid; especially it is enhanced by various stress conditions. In the GABA shunt, initially $\alpha$-ketoglutarate is converted to glutamate by glutamate dehydrogenase (GDH, EC 1.4.1.4) activity. Glutamate is then catalyzed to GABA by the activity of glutamate decarboxylase (GAD, EC 4.1.1.15). Therefore, GAD and GDH activities have important roles in the GABA pathway. In plant defense mechanism, hormone signaling has a critical role under various stresses. Therefore, the effects of plant hormones on signal molecules should be well evaluated under stress conditions [6]. And the interaction between SA and GABA is not well known. In this study, our aim was to identify the interaction between SA and GABA metabolism in pepper (Capsicum annuum L.) plants under salt and PEGinduced osmotic stresses. To our knowledge, this is the first report indicating the effect of SA on GABA metabolism during salinity and PEG-induced osmotic stresses.

\section{MATERIALS and METHODS}

\section{Chemicals and Spectral Measurements}

Hoagland, PEG, $\mathrm{NaCl}$, methanol (for liquid chromotography) were obtained from Merck. $\alpha$-ketoglutarate, dithiothreitol, Hoagland, NADPH, GABA, HN, pyridoxal-5-phosphate and Tris-HCl were obtained from Sigma Chemical Co. Borax buffer, EDTA, PVP, sodium phosphate buffer were obtained from Fluka.

\section{Growth Conditions and Stress Treatment}

The seeds of pepper plants (Capsicum annuum L.) were provided from Anatolia Agricultural Research Institute in Eskisehir, Turkey. Seeds were surface sterilized in $5 \% \mathrm{NaOCl}$ and washed with sterile water and germinated on perlite in a growth chamber under a constant day/night temperature of $26^{\circ} \mathrm{C} / 22^{\circ} \mathrm{C}$ and $16 / 8 \mathrm{~h}$ light/dark, with a light source of $175 \mu \mathrm{mol}$ $\mathrm{m}^{-2} \mathrm{~s}^{-1}$ and with a humidity of $65 \%$. The seedlings were watered regularly with $1 / 2$ Hoagland solution. After 4 weeks, $100 \mathrm{mM} \mathrm{NaCl}$ and $10 \%$ polyethylene glycol (PEG 6000) and $0.5 \mathrm{mM} \mathrm{SA}$ were applied in Hoagland solution for one week. The experiment was laid out as a randomized complete block design with three replications. The leaves $(0.5 \mathrm{~g}, 1 \mathrm{~g})$ were frozen in liquid nitrogen and then stored at $-80^{\circ} \mathrm{C}$ until analyses.

\section{Total Chlorophyll Content}

Total chlorophyll content was assayed according to [7]. The chlorophyll concentrations were calculated by the following equation.

Chlorophyll $a+b(\mathrm{mg} / \mathrm{g})=[8.02 \times A 663+20.20 \times A 645] \times$ $\mathrm{V} / 1000 \times \mathrm{W}$, Where $\mathrm{V}=$ volume of the extract $(\mathrm{ml}) ; \mathrm{W}=$ Weight of fresh leaves ( $\mathrm{g}$ ).

\section{Sample Preparation and Enzyme Assay}

Leaf samples $(1 \mathrm{~g})$ were homogenized in the buffer contained $5 \mathrm{mM}$ EDTA, $0.1 \mathrm{mM}$ Tris $-\mathrm{HCl}, 10 \mathrm{mM}$ dithiothreitol, $1 \mathrm{mM}$ pyridoxal 5 phosphate hydrate, and 1\% PVPP ( $\mathrm{pH}$ 7.8). Homogenates were then centrifuged at $10000 \mathrm{~g}$ for $10 \mathrm{~min}$ at $4^{\circ} \mathrm{C}$ according to [8]. Leaf extracts were used in the analysis of glutamate decarboxylase (GAD, EC 4.1.1.15) and glutamate dehydrogenase (GDH, EC 1.4.1.4) activities. $100 \mathrm{~mL}$ of the crude protein was used for the assay of GAD activity in a $500 \mathrm{~mL}$ reaction mixture containing $100 \mathrm{mM}$ Tris- $\mathrm{HCl}$ (pH 7.0), $0.5 \mathrm{mM}$ pyridoxal-5phosphate, $5 \mathrm{mM} \mathrm{Glu}, 1 \mathrm{mM}$ DTT, $0.5 \mathrm{mM} \mathrm{CaCl}_{2}$, and $0.1 \mathrm{mM}$ bovine CaM [9]. For determining of the GDH activity, leaf samples were added to assay mixture 
containing $50 \mathrm{mM}\left(\mathrm{NH}_{4}\right)_{2} \mathrm{SO}_{4}, 13 \mathrm{mM} \alpha$-ketoglutarate $0.25 \mathrm{mM} \mathrm{NADPH}$ and $1 \mathrm{mM} \mathrm{CaCl}_{2}$ in $100 \mathrm{mM}$ Tris- $\mathrm{HCl}$ buffer ( $\mathrm{pH} 8$ ). The activity was detected at $340 \mathrm{~nm}$ (T80+UV-VIS Spectrometer PG Instruments). The results were given as micromoles per minute gram fresh weight (FW) [8].

\section{GABA Analysis}

GABA analysis was performed by HPLC (Agilent 1200) according to [10]. Leaf samples (0.5 g) were homogenized in $1 \mathrm{~mL}$ water:chloroform:methanol (3:5:12 v/v/v) solution, then centrifuged at 10,000 rpm at $4{ }^{\circ} \mathrm{C}$ for $5 \mathrm{~min}$. The supernatant was taken and put in another sterilized tube and dried. Samples were dissolved in a mixture containing $100 \mu \mathrm{L}$ water, $150 \mu \mathrm{L}$ Borax buffer $(\mathrm{pH} 8)$ and 250 $\mu \mathrm{L}$ 2-hydroxynaphthaldehyde $(0.3 \%$ prepared in methanol). The mixture was then put on a water bath $\left(80^{\circ} \mathrm{C}\right.$ for $\left.30 \mathrm{~min}\right)$. After cooling at room temperature, $1 \mathrm{~mL}$ of methanol was added to the mixture. Samples were separated by reversed-phase column Supelco LC18 $\left(250 \times 4.6 \mathrm{~mm}^{2}, 5 \mu \mathrm{m}\right)$ at 330 $\mathrm{nm}$ with an injection volume of $20 \mu \mathrm{L}$, flow rate 1 $\mathrm{mL} \min ^{-1}$; and methanol:water (62:38 v/v) mobile phase. The retention time of GABA peak was $12 \mathrm{~min}$. Quantification was calculated by comparing the peak areas within GABA standards. We also derivatizated GABA standards with HN.

\section{Statistical Analysis}

The effect of salt, drought and combined stresses were determined using one-way variance analysis ANOVA. The treatments of means were compared by least significant difference (LSD) test at $p<0.05$ and Duncan's multiple comparison test. The spread of values is shown in the figures as standard errors of the means.

\section{RESULTS and DISCUSSION}

The Effect of Salicylic Acid on Total Chlorophyll Content Under Stress Conditions

Salicylic acid (SA) is known naturally as a plant hormone, and it is an important signal molecule in abiotic and biotic stress conditions [11]. Previous reports indicate that SA could induce the tolerance mechanism against various stress conditions such as salt [12-15], drought [16], and cold [17] stresses. SA was also suggested as a potential growth regulator in limited soil water availability [16]. However, SA application could cause an increased sensitivity to drought stress [18]. Previously it was mentioned that high concentration of SA could lead to negative effects on photosynthesis [19]. Therefore, the application process of SA is important to enhance the tolerance mechanisms under various stress conditions.

Total chlorophyll content can be used as an indicator in the determining the effects of supplements on plant metabolism. In previous reports, SA application could cause an increase in total chlorophyll content $[15,20,21]$. We are in agreement with these findings with an increase in chlorophyll content by SA application (Figure 1). However, in our study, combined salt and PEG-

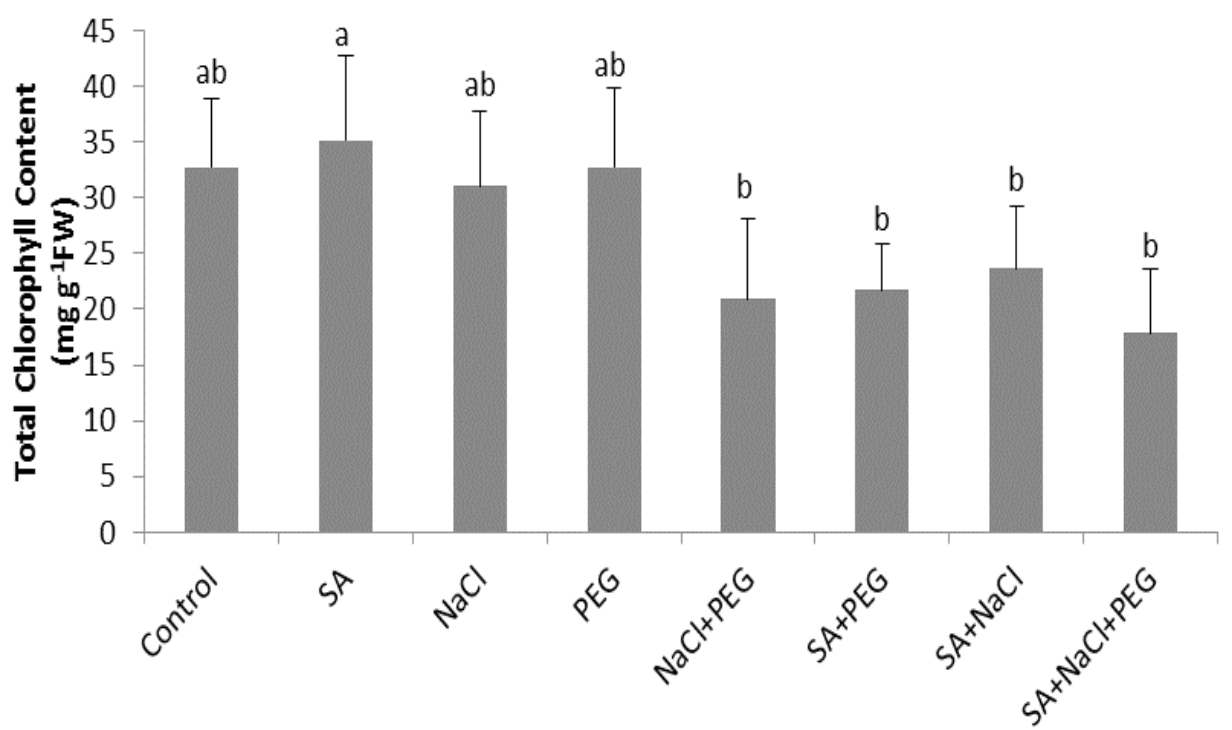

Figure 1. The effects of SA on total chlorophyll content in the leaves of pepper plants. The data represent the mean of three replications and error bars indicate SD. Different letters indicate significantly different values at p<0.05. 


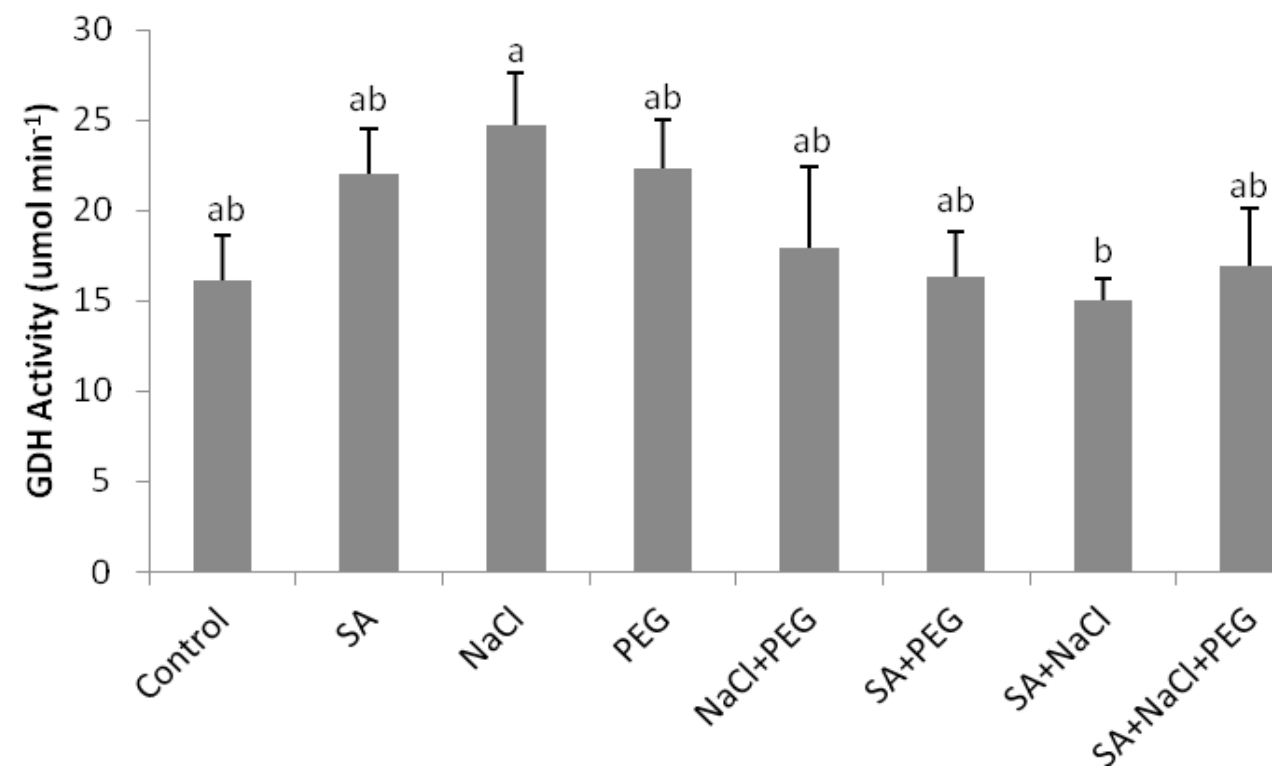

Figure 2. The effects of SA on GDH activity in the leaves of pepper plants. The data represent the mean of three replications and error bars indicate SD. Different letters indicate significantly different values at $p<0.05$.

induced osmotic stress significantly decreased total chlorophyll content when compared to control plants. Under these stress conditions, SA did not help to increase total chlorophyll content in pepper plants.

\section{The Effect of Salicylic Acid on GABA Metabolism Under Stress Conditions}

During stress, SA could have effect on the stressrelated metabolites. GABA is a non-protein amino acid, and it is known to be enhanced by various stress conditions. However, the interaction between SA and GABA is still unknown. In GABA shunt, GDH activity has important role by converting $\alpha$-ketoglutarate to glutamate which is the precursor of GABA. Glutamate can be occurred in various biochemical processes. Therefore, GDH activity is differently regulated by stress conditions $[22,23]$. We are in agreement with these studies. In our study, GDH activity was enhanced by $\mathrm{SA}, \mathrm{NaCl}$ and PEG-induced osmotic stresses as compared to control plants (Figure 2). The highest GDH activity was found under salt stress ( $p<0.05)$. However, GDH activity was found similar to control plants under the combined stress and SA+stress applications. It can be suggested that during individual stress conditions, SA might have a role in the accumulation of glutamate which could be then converted to GABA.

GAD, the key enzyme in GABA-shunt, catalyzes the conversion of glutamate to GABA. The earlier studies indicate the increase in GAD activity under $\mathrm{NaCl}$ stress and also supplemental of $\mathrm{CaCl}_{2}[24,25]$. In our study, GAD activity was increased especially by $\mathrm{NaCl}, \mathrm{NaCl}+\mathrm{PEG}$ and SA+PEG-induced osmotic stresses ( $p<0.05$, Figure 3 ). The highest GAD activity was found under $\mathrm{NaCl}+\mathrm{PEG}$ applied plants (Figure 2). Under these stress conditions, GABA contents showed an increase and it could be correlated with GAD activity. However, GAD activities in individual salt and PEG-induced osmotic stresses were not exactly correlated with GABA content. This might be as a result of GABA transaminase activity, which catalyzes succinic semialdehyde (SSA) to GABA. In this pathway, GAD activity might not be active. Moreover, the polyamine degradation pathway could respond in GABA accumulation without GAD activity. Polyamines could be converted into GABA by the activity of polyamine oxidase and diamine oxidase $[22,23]$.

Increased GABA accumulations were reported in various stresses such as drought, salt, and heavy metal stresses. In our study, individual or combined $\mathrm{NaCl}$ and PEG-induced osmotic-stresses caused an increase in GABA content of pepper plant (Figure 4). We are in agreement with Akama and Takaiwa [26] and Mekonnen et al. [27] with the increase in GABA accumulation under salt and PEG-induced osmotic stresses. However, SA application did not enhance GABA content even under stress applications as 


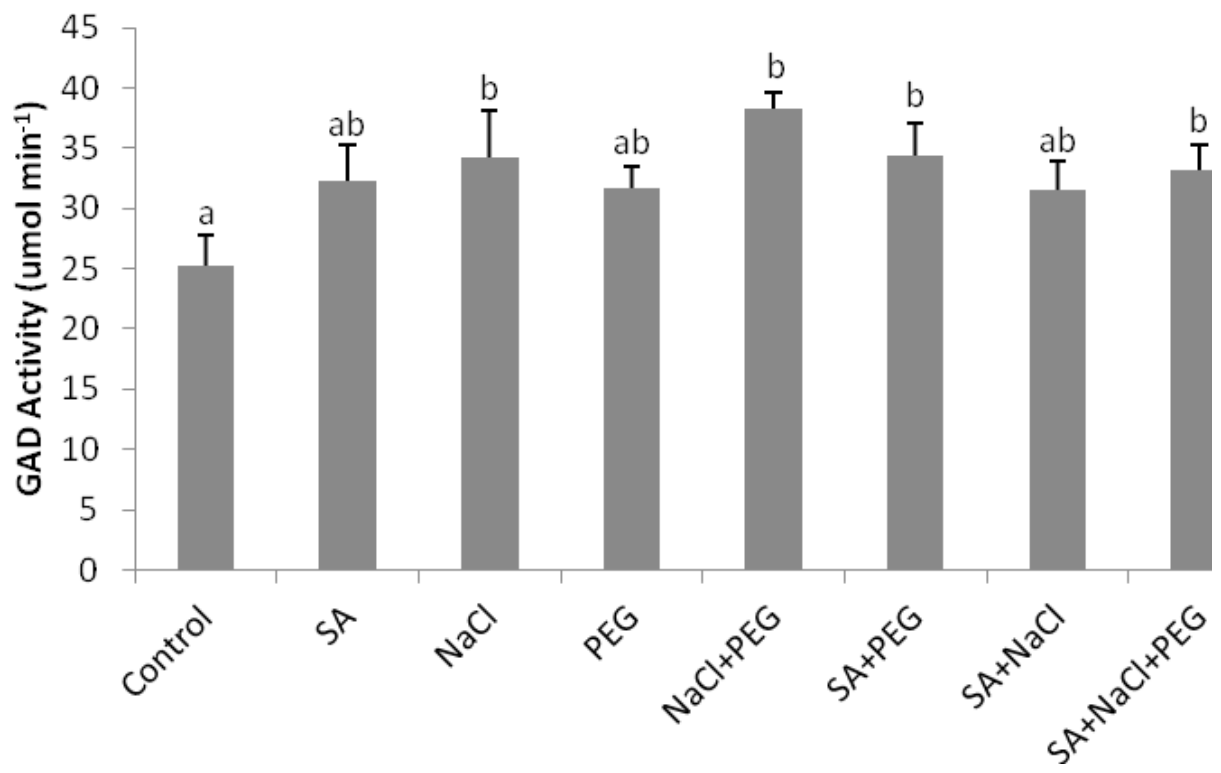

Figure 3. The effects of SA on GAD activity in the leaves of pepper plants. The data represent the mean of three replications and error bars indicate SD. Different letters indicate significantly different values at $p<0.05$.

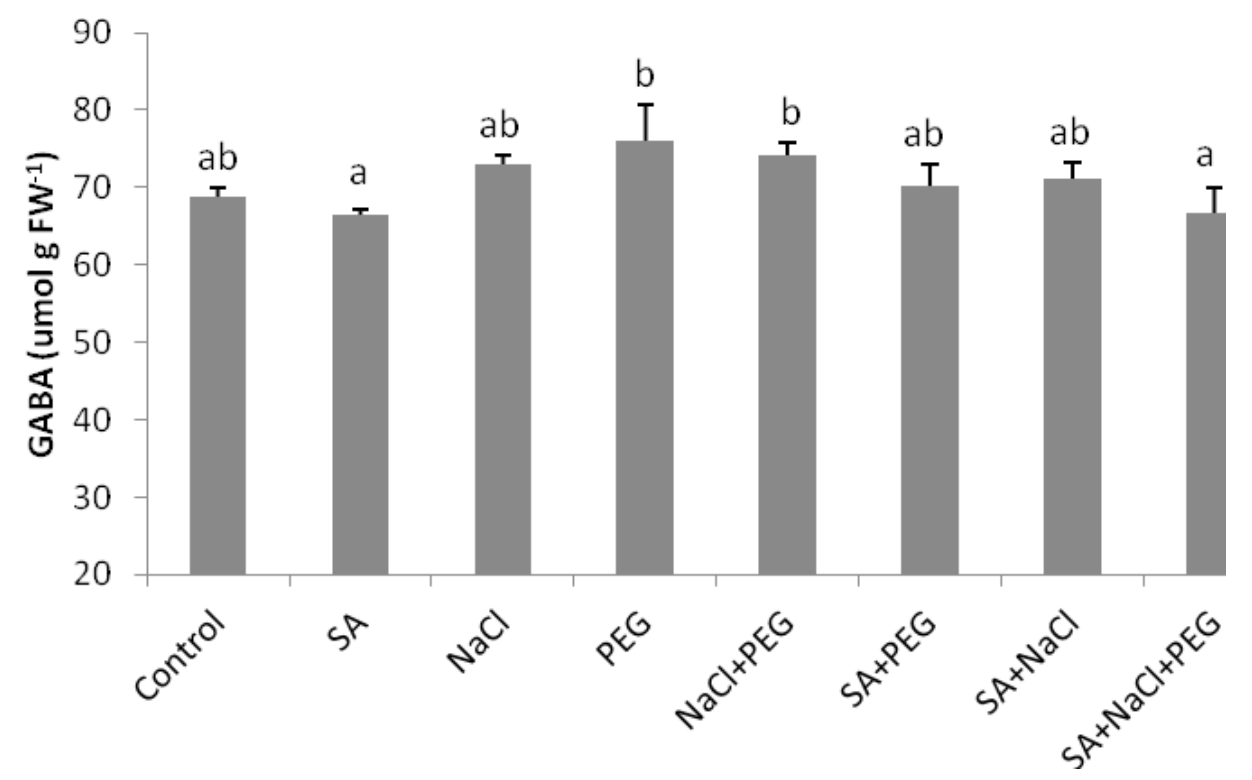

Figure 4. The effects of SA on GABA content in the leaves of pepper plants. The data represent the mean of three replications and error bars indicate SD. Different letters indicate significantly different values at $p<0.05$.

compared to control plants. Also, we did not find any remarkable difference between the combined salt and PEG-induced osmotic stress applications. We could suggest that $0.5 \mathrm{mM} \mathrm{SA}$ could cause a decrease in GABA content. In addition, GABA accumulation and GAD activity of pepper plants were not exactly correlated under these stress conditions.

According to Akçay et al. [23], GABA accumulation could be related to have a better growth in stressed conditions under long term salinity. In response to stress conditions, plant hormones could have an important role. Supplemental of different substances could interact with GABA metabolism. Daş et al. [28] indicated that $\mathrm{Zn}$ addition could help to increase activities of GABA-shunt enzymes. Moreover, ABA could increase GAD activity and GABA content [25]. In pepper plants, salicylic acid did not cause a significant GABA accumulation in individual and combined stress conditions. The dose and the application process of SA could lead to this result. Therefore, further analyses should be done for identifying the effect of SA on GABA metabolism especially in single and combined stress conditions in different plants, and also the relationship between GABA and stress-related hormones should be well identified. 


\section{ACKNOWLEDGMENTS}

This study was supported by Aksaray University Research Council (Project number 2014-006). The author would like to thank Dr. Melike BOR, Department of Biology, Ege University, for providing useful comments on GABA analysis.

\section{References}

1. L.V. Kurepin, A.G. Ivanov, M. Zaman, R.P. Pharis, S.I Allakhverdiev, V. Hurry, N.P.A. Huner, Stress-related hormones and glycinebetaine interplay in protection of photosynthesis under abiotic stress conditions, Photosynth. Res., 2 (2015) 221-235.

2. MR. Vicente and J. Plasencia, Salicylic acid beyond defence: its role in plant growth and development, J. Exp. Bot., 62 (2011) 3321-3338.

3. N. Hashmi, MMA. Khan, M. Idrees, T. Aftab, Exogenous salicylic acid stimulates physiological and biochemical changes to improve growth, yield and active constituents of fennel essential oil, Plant Growth Regul., 68 (2012) 281-291.

4. O. Borsani, V. Valpuesta, M. Botella, Evidence for a role of salicylic acid in the oxidative damage generated by nacl and osmotic stress in Arabidopsis seedlings, Plant Physiol., 126 (2001) 1024-1030.

5. E. Horváth, G. Szalai, T. Janda, Induction of abiotic stress tolerance by salicylic acid signaling, J. Plant Growth Regul., 26 (2007) 290-300.

6. H. Derksen, C. Rampitsch, F. Daayf, Signaling crosstalk in plant disease resistance, Plant Sci., 207 (2013) 79-87.

7. D.I. Arnon, Copper enzymes in isolated chloroplasts. Polyphenoloxidase in Beta Vulgaris., Plant Physiol., 24 (1949) 1-15.

8. O. Yolcu S. Filiz, B. Melike, Gamma-amino butyric acid, glutamate dehydrogenase and glutamate decarboxylase levels in phylogenetically divergent plants, Plant Syst. Evol., 299 (2013) 403-412.

9. T. Akihiro et al., Biochemical mechanism on GABA accumulation during fruit development in tomato. Plant Cell Physiol., 49 (2008) 1378-89.

10. M. Bor, B. Seckin, R. Ozgur, O. Yılmaz, F. Ozdemir, I. Turkan, Comparative effects of drought, salt, heavy metal and heat stresses on gamma-aminobutryric acid levels of sesame (Sesamum indicum L.), Acta Physiol. Plant., 31 (2009) 655-659.

11. M. Abedini and B.D. Hassani, Salicylic acid affects wheat cultivars antioxidant system under saline and non-saline condition, Russ. J. Plant Physiol., 62 (2015) 604-610.

12. A. Gunes, A. Inal, M. Alpaslan, F. Eraslan, E.G. Bagci, N. Cicek, Salicylic acid induced changes on some physiological parameters symptomatic for oxidative stress and mineral nutrition in maize (Zea mays L.) grown under salinity., J. Plant Physiol., 164 (2007) 728-36.

13. L.A. Tuna, C. Kaya, M. Dikilitas, I. Yokas, B. Burun, H. Altunlu, Comparative effects of various salicylic acid derivatives on key growth parameters and some enzyme activities in salinity stressed maize (Zea mays L.) Plants, Pakistan J. Bot., 39 (2007) 787-798.
14. D. Khoshbakht and MR. Asgharei, Influence of foliarapplied triacontanol on growth, gas exchange characteristics, and chlorophyll fluorescence at different growth stages in wheat under saline conditions, Photosynthetica, 53 (2015) 410-418.

15. A. Baghizadeh, MR. Salarizadeh, F. Abaasi, Effects of salicylic acid on some physiological and biochemical parameters of Brassica napus L. (Canola) under salt stress, 4(2014) 147-152.

16. A. Bideshki, M.J. Arvin, M. Darini, Interactive effects of Indole- 3-butyric acid (IBA) and salicylic acid (SA) on growth parameters, bulb yield and allicin contents of garlic (Allium sativum) under drought stress in field, Int. J. Agron. Plant Prod., 4 (2013) 271-279.

17. S. Mutlu, Ö. Karadagoglu, Ö. Atici, B Nalbantoglu, Protective role of salicylic acid applied before cold stress on antioxidative system and protein patterns in barley apoplast, Biologia Plantarum, 57 (2013) 507513.

18. M. Németh, T. Janda, E. Horváth, E. Páldi, G. Szalai, Exogenous salicylic acid increases polyamine content but may decrease drought tolerance in maize, Plant Sci., 162 (2002) 569-574.

19. M.A. Gururani, T.K. Mohanta, H. Bae, Current understanding of the interplaybetween phytohormones and photosynthesis under environmental stress, Int. J. Mol. Sci., 16 (2015) 19055-19085.

20. M. Arfan, H.R. Athar, M. Ashraf, Does exogenous application of salicylic acid through the rooting medium modulate growth and photosynthetic capacity in two differently adapted spring wheat cultivars under salt stress?, J. Plant Physiol., 164 (2007) 685-94.

21. A. Ghasemzadeh and H.Z.E. Jaafar, Interactive effect of salicylic acid on some physiological features and antioxidant enzymes activity in ginger (Zingiber officinale Roscoe)., Molecules, 18 (2013) 5965-79.

22. F.J. Turano, S.S. Thakkar, T. Fang, J.M. Weisemann, Characterization and expression of $\mathrm{NAD}(\mathrm{H})$-dependent glutamate dehydrogenase genes in Arabidopsis., Plant Physiol., 113 (1997) 1329-1341.

23. N. Akçay, M. Bor, T. Karabudak, F. Ozdemir, I. Türkan, Contribution of Gamma amino butyric acid (GABA) to salt stress responses of Nicotiana sylvestris CMSII mutant and wild type plants, J. Plant Physiol., 169 (2012) 452-458.

24. Y. Yin, R. Yang, Q. Guo, $\mathrm{NaCl}$ stress and supplemental $\mathrm{CaCl}_{2}$ regulating GABA metabolism pathways in germinating soybean, Eur. Food Res. Technol., (2014) 781-788.

25. R. Yang, Q. Hui, Z. Gu, Effects of $A B A$ and $\mathrm{CaCl}_{2}$ on GABA accumulation in fava bean germinating under hypoxia- $\mathrm{NaCl}$ stress, Biosci. Biotechnol. Biochem., 80 (2016) 540-546.

26. K. Akama and F. Takaiwa, C-terminal extension of rice glutamate decarboxylase (OsGAD2) functions as an autoinhibitory domain and overexpression of a truncated mutant results in the accumulation of extremely high levels of GABA in plant cells, J. Exp. Bot., 58 (2007) 2699-2707.

27. D.W. Mekonnen, U.I. Flügge, F. Ludewig, Gammaaminobutyric acid depletion affects stomata closure and drought tolerance of Arabidopsis thaliana, Plant Sci., 245 (2016) 25-34.

28. Z.A. Daş, G. Dimlioglu, M. Bor, F. Özdemir, Zinc induced activation of GABA-shunt in tobacco (Nicotiana tabaccum L.), Environ. Exp. Bot., 122 (2016) 78-84. 